Y ahora que vas a hacer mulata?

published in Women and Performance: a journal of feminist theory. November 2008, Issue 18:3

Melisa Blanco Borelli

Abstract:

This essay examines the film Mulata (1954) starring Cuban vedette Ninón Sevilla through the various performances of mulata identity featured in the film. By introducing the theory of hip(g)nosis and the sentience corpo-mulata, these theoretical models demonstrate how a body racialized as mulata choreographs identity through gestures, bodily articulations, and sociohistorically inscribed movement repertoires associated with this particular corporeality. The development of these terms intends to show the complexities that bodies add to history, as well as their impact on cultural production and notions of territoriality, nationalism, and citizenship. These terms also highlight the pleasure, sensuality, and affect involved in identity construction. Finally, by providing examples of these theories through a close reading of Ninón Sevilla's performances of the title character in the film Mulata, the essay provides a way to re-think the mulata as something other than "tragic."

Subtle lighting envelopes tables and chairs ...cigarette smoke dances in the air. Glasses sound against one another. Glasses, filled with tequila or rum, and held by men's gnarled hands. Alcohol to assuage a wounded masculinity that hides beneath heavily invested performances of machismo. Suddenly, the sound of maracas, drums, pounding, pulsing ... a bright spotlight shines upon a curvaceous figure ... a woman. Not just any woman, but a rumbera, a woman dancing rumba ... or mambo, or cha-cha-cha-Cuban rhythms. Her hips, decorated with sequins, feathers or fringe, move to the incessant rhythm of the drums, hips swaying, pulsing, rotating and gyrating. Audience's eyes transfixed. Hip-notism.

What I have briefly described alludes to scenes found in many of the films from Mexican cinema's golden age, particularly the cabaretera or cabaret genre. During this time from about 1935-1959, many Cuban vedettes were literally imported to Mexico in order to perform AfroCaribbean/Cuban dances in elaborate musical numbers. Mexican film popularized the archetype of the "rumbera," a sultry, seductive woman who enticed her audience with transgressive body movements, specifically her ever revolving hips dancing rumba. The rumba, a highly eroticized and heterosexual dance, evokes a pre-coital mating game when danced with a partner. In contrast, these rumberas, danced alone, moving their hips and enticing anyone and everyone to partner with them. The rumba, as a dance "historically derived from associations with Cuba's black underclass, their lifestyles, attitudes and cultures," was somewhat sanitized by the rumba dancing mulata characters made popular in Cuban theatrical stage productions of the late nineteenth/early twentieth century (Moore 1997, 169). The dance, still coded as dark and underclass, gained certain respectability performed by a lighter-skinned body, accentuating the erotics of the mulata body, particularly her hips. The rumba was further eroticized when predominantly white Cuban bodies, such as Ninón Sevilla, exported and displayed it on Mexican film, extending its association not just with Cuban mulatas, but a feminized cubanidad based on ample, agile, and entrancing hips. It is from these be-witching hips where the idea of hip-notism, and the ensuing theory of $\operatorname{hip}(\mathrm{g})$ nosis arises. This essay begins with introductions to the theory of hip $(\mathrm{g})$ nosis and to the 
corpo-mulata: two ideas I have developed in my book length project in order to contest the idea of the mulata as a merely tragic figure of colonialism. These terms/theories demonstrate how a body racialized as mulata choreographs identity through gestures, bodily articulations, and socio-historically inscribed movement repertoires associated with this particular corporeality. By developing this sign/theory/movement and the sentience "corpo-mulata," my intention is to show the complexities that bodies add to history, as well as their impact on cultural production and notions of territoriality, nationalism, and citizenship. Finally, by providing examples of these theories through a close reading of Ninón Sevilla's performances of the title character in the film Mulata, I provide a way to re-think the mulata as something other than "tragic."

Mulata depicts various stereotypes of the mulata figure, among them: fatherless, poor, virtuosic dancer, sexualized yet infantilized, and of course, tragic. Many other characters in the film are reminiscent of Cuban teatro bufo: a gallego man who lusts after the mulata, the gallego's wife/counterpart who dislikes the mulata, a mulato suitor, and a white suitor. Despite the limited and stereotypical qualities assigned to the mulata in the film, Ninón's Caridad (this particular name tying her to la Virgen de la Caridad del Cobre, the mixed-race patron saint of Cuba that is syncretized with the Santería goddess Ochún) offers a nuanced rendition of the tragic trope. Although Ninón's Caridad does die at the end, her death signifies a return to her matrilineal heritage, and the culmination of her life's journey to be in a "place" where her color and black inheritance do not matter. This mulata must leave the material world as it has no place for her. Her path to this "transcendence" includes several hip shaking moments where she asserts her material reality as a corpo-mulata using hip(g)nosis. Although the film Mulata remains marred by the trope of the tragic, displaced, desired yet unloved mulata, it demonstrates how a corpo-mulata might utilize her interpellated status as a means for survival. The mulata's demise caused by the excesses associated with the cabaret and her mulata-ness neatly package the widely-circulated and -known mulata trope throughout Spanish speaking America (safely assuming that audiences in countries in Latin America other than Mexico and Cuba saw the film). Despite the notoriety and circulation of the trope, I am suggesting an almost counter-intuitive means of watching the film, the choreography, and Ninón's body through the theories of hip(g)nosis and the materialization of the corpo-mulata. As theories based on corporeal knowledge and rhetoric, they enable a body-in this case Caridad's ficitional one, and Ninón's "real" one-to contest the narrative implicit in mulata-ness.

A fascination with the mulata's shaking hip appears in literary scholar José Piedra's essay "Hip Poetics." In it, Piedra turns to the Cuban dance form of the rumba as a way to both read the body of, and find a voice for the rumbera, the "woman-of(f)-color" dancing rumba. He notes in his article "Hip Poetics" that the "[r] umba provides a partial form of liberation and also a form of revenge that shakes and undresses the motives of those who watch to pay for the shaking and the undressing" (107). He further elaborates:

a rumbera [usually with mulata characteristics] is not simply a person who exists through her hips and her duties to men but also through her own mind and rights. The rumba hips, exaggerated, voyeuristic, exhibitionist, deified, and prostituted as they might appear to be, might also be a signifier of both acceptance of our bodies and defiance of foreign impositions, and even further: a substitute for the silenced or muffled voice, and not just for women or through women (108).

Influenced by Piedra's postulations, I diverge from his examples of the hip as a source of liberation for women in that I don't read the hip as a static text. His analysis comes from textual examples of rumbera hips as canonized in Caribbean literature and poetry. In contrast, the hips that I refer to belong to corpo-realities constantly moving them. I am interested in the visceral, the corporeal, the flesh moving, sweating, watching and being watched. Following 
the example of Saidiya Hartman, I have chosen to begin "counterinvesting in the body as a site of possibility" (51). If mulata is incarcerated by its own cultural constructions, why not liberate it by the corpo-mulata's own pleasurable performance of those cultural constructions?

The shaking, rotating, revolving hips usually associated with primitive sensuality and vacuous carnality become a repertoire of movement associated with not just a Cuban body, but particularly a Cuban mulata body - la mulata de rumbo, a costumbrista adage used to connote the mulata of the party, the unstable mulata, the mulata that always searches for a party. It is this archetype of the mulata that Ninón Sevilla's "brownface" performances both engage and contest. The pleasure her mulata character finds in her body's liberation from, yet enactment of, mulata-ness crystallizes how historically marginalized corporealities utilize their bodies as sites of defiance, empowerment, and sensual affront. In this vein, how could a living body ever be tragic?

\section{La Corpo-Mulata Rumbera and Hip(g)nosis}

Both a history and a lived experience, the mulata exists primarily as a narrative trope. The body is read as if it is separate from its inhabitant. Further, this distance between the person who is a mulata and the trope that binds the mulata creates a series of tragic mis-encounters with the social as the person who lives the reality is engaged as a living character in an extended melodrama, not a material witness, to social processes and machinations of power. The real tragedy here is not the body as evidence of miscegenation, but the violence of language. For these reasons, I have constructed the sentience, "corpo-mulata." The term corpo-mulata serves as a means to address the method through which different corpo-realities use, manipulate, (de)activate, subdue, and mobilize the various signifiers of "mulata" within this market-space of colonized histories. Corpo-mulata exists as a confluence of different factors: colorisms stemming from colonial hierarchies based on skin color, gendered realities, monetized sexual exchanges and realities, and distinct processes of domination depending on which type of patriarchal system acted as the hegemonic power. Additionally, a corpo-mulata foregrounds the discourses and debates about purity, beauty, and truth. The hybridized, miscegenated, mulaticized body-otherwise known as the corpomulata-disrupts these idealized conditions constructed by the Western cultural imaginary. As a type of narration, the mulata disappears. She becomes tragic, a victim of historical and literary representations based on hegemonic discursive practices. Yet, as a materiality, as a corpo-mulata, she is always present and visible, staking out space, territory, and meaning. More importantly, she is powerful through this materiality as represented through her hips and their transnational indexicality. As a result, the corpo-mulata is not a laborless body, but one that actively labors by problematizing how definitions of beauty and purity affect its interpellation and how the machinations of history amplify said interpellation. Corpo-mulata exists as an incorporated marking. It is a widely distributed and recognizable "embodiment" or character that pertains to specific market forces and systems of interpellation primarily between a Europeanness and an Africanness, sauntering into a "New World-ness." Corpo-mulata can be circulated like capital, expended, used, and wielded. Unlike an uttered performative, like the "I do" of J.L. Austin's "How to Do Things with Words," the corpo-mulata as a body is not a linguistically-driven state of being. When a corpo-real choreographs corpo-mulata, she uses the incorporated markings of the corpomulata performance and mobilizes them through bodily gesture.

Caught within the mulata trope, a corpo-mulata has situational agency, not projected agency. She cannot completely decide for herself how she wants to be seen because her body pertains to an economy of visibility within which it is assigned loaded signifiers: they supersede her. In the film Mulata for example, Ninón Sevilla as the mulata Caridad is stereotypically hailed 
as mulata cochina (dirty mulata), mulata asquerosa (filthy mulata), and at one point as having "el diablo metido en (su) cintura (the devil in her waist)" because she presumably "tempts" men with the sway of her moving body. The mulata can also have aesthetic agency because of the different forms of value imposed on her skin, body, hair, or features, and then use this aesthetic agency to its advantage (or not). Yet without hip(g)nosis, the corpo-mulata has no potentiality to be anything more than an amalgam of signifiers speaking for her across her skin on her behalf in the service of white patriarchal capital formations. Signifiers will always speak due to their culturally defined circulation, yet they do not speak a body into being, only into knowing. Although her sign labors for her, a corpo-mulata exerting hip(g)nosis allows the body to dialogue and even overtake the battery of signs over-working the body even when it is still. Hip $(\mathrm{g})$ nosis provides a method for a corpo-real to actively organize how the mulata signifiers dance around its physiological facts. Thus, materializing as a corpo-mulata, she can contest the fixity of the mulata-sign and mobilize it in order to dismantle the tragedy inherent in it.

The genesis of the term/theory hip(g)nosis stems from a play on the words hip, hypnotism, and gnosis. By evoking the trance-like state of hypnotism, I consider the audience reaction to dancing mulatas, specifically remembering the mulatas I witnessed at the Tropicana cabaret in Cuba during one of my research trips. I place the " $\mathrm{g}$ " in parentheses to highlight its usefulness in associating certain hip movements to choreographies of worship in Africanist/Lukumí praise dancing featured in the film Mulata, while at the same time allowing for hip movements or hip-nosis to be a theory of corporeal knowledge not specifically linked to Africanist cosmology, for example when the mulata in the film dances the secular cha-cha-cha. Either way, the corporeal knowledge shared through the mobilization of the corpo-mulata's hips asserts the powerful force of her body and its nontragic state.

Power lies always-already in the hip, but only those conversant in this particular corporeal language have access and can understand its multi-layered knowledge. That is to say, only those that can accept kinesthetic knowledge as valuable and female-made cultural production as essential can "hear" what these hips say. Mere reliance on the visual component of hip(g)nosis brings forth a hypnotism which counters what the corpo-real's hips mobilize and, more importantly, express - a lived, gendered and racialized history.

Just as any body can witness and/or comprehend hip(g)nosis, any body can have access to, and perhaps even wield, hip(g)nosis. But, hip(g)nosis does depend on specific histories and technologies of power. A movement is not simply a movement, but a sum of its parts-the ideologies and histories where said movement developed, gained notoriety, value, and carved out space. Additionally, as a historicized bodily theory situated in specific racial and gendered states of being, hip(g)nosis problematizes the hips' own commoditization. What happens when differently privileged bodies learn, use, and wield hips, and what does it mean for the flows of/between corporeal knowledges? Any body's access to hip(g)nosis or performance of hipped enunciations demarcates the risks in de-historicizing and removing the labor intrinsic in hip(g)nosis.

I want to draw a relationship between this claim I am making and what Anna Beatrice Scott writes in "Dance," the essay featured in Culture Works: The Political Economy of Culture. She states, "[i]f dance is particular to the body that performs it-and that body is a person particular to a certain family, locale, region, nation-then dancing takes on meaning as an identity marker and demarcates territory, both real and imagined. Crossing these boundaries engages discourses of power, and requires scrutiny of the concepts of authenticity, appropriation, misinterpretation, and misuse" (108). Hip movements can be practiced and learned, for a body is pliable and capable of being docilized in order to mobilize musculatures in disparate ways. This exposes hip movements as consumable and commodified forms, not 
as natural qualities of a body. As a commodity, hip movements then can be branded, packaged, and sold by anyone.

This branding of hipped activity results in an opportunity for the corpo-mulata to be an agent in her own self-making. These forms of technique and muscle memory substantiate Anna Scott's claim that "muscle memory is not only epic and explosive, but traverses and manipulates space and time in its various manifestations, creating potential ruptures in hegemonic perceptive devices by simultaneously stripping and manipulating sight/vision of its primacy." (Scott 2002, 6). Rather than merely looking at the curve of the hip, consider its movements as speech, its paths as drawings of a map, a space where similarly literate bodies might find moments of connection, cohesion, and relevance.

If hip(g)nosis is a repertoire associated with a corpo-mulata's hip and/or identity, how does this repertoire continue to exist through time and space? What shared histories and hipped utterances might connect hip(g)nosis outside of Cuba where I ground my genealogy, not as an originating point but as a corporeal rhetorical device? As a trans-territorial bodily theory, hip (g)nosis interpolates (in the mathematical sense) different nationalized bodies. Because of this, hip(g)nosis does not have to remain solely attached to the Cuban cultural context that I use to theorize it; it can traverse time and territory. As a result, hip(g)nosis appears on Mexican celluloid, wielded first by a Puerto Rican mulata, Mapy Cortes, who was the first rumbera and "showed her aptitude" in Cinco Minutos de Amor (Five Minutes of Love), then later by many white Cuban women - among them were María Antonieta Pons, Rosita Carmina, and Ninón Sevilla-and eventually by an American born dancer of swedish/Spanish and French-Tahitian ancestry, known as Tongolele. These were performances of racialized and nationalized hips, yet commercially elided by the signifier of the rhythmic and universalized "Latina" product covered in ruffles. In other words, the hip-notism of the mulaticized product under the guise of "Latina" enabled the dissemination of such a product specifically in the cabaretera films of Mexico's Golden Age.

\section{La Mulata Caridad}

Ninón Sevilla was born in Cuba and is famous for her performances of cubanía in Mexican films of the 1940's and 1950's. She capitalized on Mexico's Golden Age of Cinema as a rumbera-cabaretera archetype, moving her hips beneath ostentatious outfits in films like Aventurera, Perdida, and Sensualidad and playing a Cuban mulata in Mulata and Yambaó. She choreographed her own dance numbers and was instrumental in introducing Santería/Afro-Cuban ritual dances into her choreography. Ninón serves as an example of someone who traffics in hip(g)nosis. In the film Mulata, she inhabits a materiality that doesn't belong to her, that of the rumba-dancing mulata, but because of territoriality-her (white) Cuban dancing body-she's able to use hip(g)nosis and become a corpo-mulata to gain both economic and cultural capital. So although in the film Mulata she plays a "tragic mulata," Ninón was quite the contrary. In this film, two versions of hip(g)nosis appear: the fictional Caridad's quasi-liberation through her dancing, and Ninón's own use of hip(g)nosis as a brand signifying Cuba in order to achieve fame in Mexico and Latin America in the cabaretera genre.

The narrator of this tale is Martín (played by Pedro Armendariz, a famous Mexican actor from their Golden Age), an errant sailor who arrives in Cuba. We are on his boat as he watches over Caridad (Ninón Sevilla) who lies feverish in bed, mumbling inaudibly to herself. His narration introduces Caridad with a loaded term, "poor," setting her up as tragic from the beginning. He tells his tale of Caridad through flashback, his narration of Caridad's story situating her in a masculinist, linear history, a history antithetical to the motion of her hips. We only gain access to Caridad through Martín's memory. Only when she dances and expresses her history and inheritance from her mother (her Africaninity), or more precisely, 
when she enacts a corpo-mulata wielding hip(g)nosis, does she liberate herself successfully from the rigidity of the term "mulata" and its non-subject status in the film as exemplified by the address, "mulata." Except for three instances, she is never referred to by her name, Caridad. She is simply called "mulata." In this non-naming, Caridad's subjectivity not only remains unrecognized, but she becomes an interchangeable, expendable, and commodified object, her body plagued by the interpellations assigned to it by circulating ideologies. Caridad continually refers to her strong relationship to "blackness," her inheritance of the legacy of Santería left by her mother, and the limited opportunities she has as a mulata. When she shares her history with Martin, he dismisses her "inheritance of old stories" as worthless. For him (as a representative of patriarchy and "proper" history) these circulated texts of orichas (deified forces of nature in Yoruba/Santería cosmology), her legacy of "blackness," and her consistent contextualization of her racialized identity are of no value because they are not tangible, visible. His proof for the importance of things stems from occularcentrism. He says that it is better to focus on the tangible or material things that one can touch-"tocar [cosas] como tú ... ven, descansa y olvídate de todo" ("touch things like you ... come, rest and forget about everything"). His insistence that she forget and acquiesce to his desires instantiates how her corporeally-situated history not only comes secondary, but takes no precedence over the power contained within patriarchal desires. She is just an object for him and will only be situated in history as a thing in his ledger books.

Caridad's dancing ability in the film is constructed as "natural" and instinctive. Even she claims she doesn't know where her natural affinity for dance comes from; somehow it is part of her bodily composition. Alluding to Caridad's inheritance of "blackness," these danced iterations of her identity outside of the confines of the tropical "mulata," are where I witness Caridad's hip(g)nosis in the film. In these moments, unmarred by others' descriptions of who she is/what her body does, her hips forcibly speak about all of those things that Martín insists she forget. What follows are three moments in the film where Caridad-cum-corpo-mulata displays hip(g)nosis, contesting the rest of the film's tragic premise of the "poor mulata."

\section{The Bembé}

While working at the tavern owned by the gallego couple, Caridad hears batá drums (drums used for Lukumí/Santería worship). A bembé (celebration for the orichas) takes place at the nearby beach and she feels "drawn" to these "ancient rhythms." In response to the gallego's orders to continue working, she says, "I can't hear anyone, they're calling me"-the they being her ancestors. When she finally joins the group of worshippers on the beach, they are singing/dancing/praying to Ogún, the energetic force deified as the god of iron. The bembé proceeds through various oricha songs and dances: Ochosí, Yemayá, Ochún, and Changó. The bembé scene alternates between shots of the bembé with Ninón/Caridad photographed mid-thigh up, waist up, never close up, surrounded by Lukumí/Santería practitioners dancing alongside her. Wide shots from above the circle of worshippers moving to mid-frame focus of Ninón flanked by other (darker) women are interspersed with shots of the observers from the gallego's tavern. Until Caridad begins to dance Ochún, the observers at the tavern are never really watching. They hear the drumming, make comments and then the camera cuts away from their tête-a-tête back to the bembé. However, once the bembé for Ochún begins and Ninón/Caridad breaks away from the group and begins to dance at first with two women on either side of her, and then alone, the camera returns to the tavern where it focuses on a medium shot of Martín for the first time. A solo shot of Ninón/Caridad from her mid-thigh upwards is followed by one of Martín staring at her. Martín watches enraptured, ignoring the advances of another woman:

Confiesa, la esperas, verdad? [...] Olvídate de esa mujer, te puede embrujar. Es hija de santera. 
Confess, you're waiting for her, right? [...] Forget about that woman, she can bewitch you. She's a santera's daughter.

His hypnotized gaze metonymically represents the heterosexual male gaze that sexualizes Ninón/Caridad's worshipping body, and hence Ochún as a godforce as well (See Figure 1).

Figure 1. Video Still from Mulata (1954), Photo by Author. Martín (Pedro Armendáriz) looks out at bembé where Caridad dances.

Ninón/Caridad's hips subtly sway from side to side as she alternately places one foot in front of the other in place, dancing the basic Ochún step. Her arms are usually held away from her torso, from shoulder joint to elbow perpendicular to her torso, from the elbow joint to her hands parallel to her torso. Sometimes, when she becomes invigorated by the music (or the singing and dancing), the intensity through which she executes the movements increases. Her dancing strength is much more evident compared to the two women on either side of her. They barely move their arms and just keep the rhythm with their feet. Ninón/Caridad picks up her skirts and we catch glimpses of her thighs, then she dips and spins around and moves away/out of the imaginary horizontal line created by her and the other two women. Martín's narration contributes to the mounting energy of the bembé and Ninón/Caridad's dancing (See Figures 2, 3 and 4).

Figure 2 Video Still from Mulata (1954), Photo by Author. Caridad dances Ochún at the bembé.

Figure 3. Video Still from Mulata (1954), Photo by Author. Close up of Caridad dancing Ochún at the bembé.

Figure 4. Video Still from Mulata (1954), Photo by Author. Caridad's dancing to Ochún becomes livelier and she begins to use her skirt.

Ochún's dance is followed by Ochosi, the deity associated with hunting. Martín/narrator erroneously attributes the hands coming together with two fingers forming a cross-a gesture representing the bow and arrow that Ochosi as the hunter carries with him-as calls to the virgins (saints) and ancestors (Caridad's mother) they venerate. The music changes again. Martín/narrator continues to explain that now they are praising Changó, the deified force of male virility. Although the narrator speaks about Changó, the drumming and song belong to Ochún: "Kole wa ye o"-this chant corresponds to the apataki, or tale, where Ochún becomes a vulture to take a message from Earth to Olodumare. The choreostory loses its meaning and gets misinterpreted as a masculine deity's tale, removing its significance in this instance. However, during the "Kole wa ye o," Caridad falls to the ground, overcome. She shakes furiously and uncontrollably. In bembés, falling signifies the appearance of egún (ancestor spirits), not the arrival of the deity (Ramos, personal communication with author, 2006). However, in the film, her fall is misinterpreted as a possession. A more alarming moment follows. When the drumming/singing changes to Elegua suddenly (primarily due to the film's image and sound editing), other women begin to fall down and strip from the waist up, revealing their breasts while writhing sexually on the sand. According to one of my Ifa/Lukumí consultants, nakedness at a bembé implies disrespect. Cuban cultural scholar Reynaldo González corroborates this claim:

Los aspectos "rituales" que muestra el filme están lejos de reflejar actos verdaderos de la Regla de Ocha o Santería, donde el nudismo de los oficiantes se consideraría profananción de las deidades que adoran. 
The "ritual" aspects that the film depicts are far from the true acts of la Regla de Ocha or Santería, where the nudity of its practitioners would be considered the profanation of the deities they worship (106).

Chants echoing Ochún: "Ala Om' Ashe 'M Ashe" "Ala Omo Ashe/ Omo Ashe” (loosely translated, The Child that is covered with godforce) echo throughout the film. Later, this chant "calls" Caridad "home" right before she dies on Martín's boat. She is finally free, Martín tells us, her death symbolizing her freedom from the lexical constraints of the material world.

Hip(g)nosis speaks a boisterous, rambunctious language especially for those who can follow it. Here, hip(g)nosis reveals its sleight of hand, or more accurately, sleight of hip. Although floating signifiers want to forcibly envelop the corpo-mulata and silence her, hip(g)nosis forces the focus to the body wielding it and choreographing corpo-mulata. Bodies set these markers of identity into play. And, by choosing to perform whatever aspect of corpo-mulata necessary for agency and recognition, Caridad enacting hip(g)nosis has some agency in how she is perceived. Such hip(g)nosis occurs on the cabaret stage where she becomes a star.

\section{El Cabaret Las Vegas}

Martín takes Caridad to Havana where he brings her to a cabaret. While she sits and watches him surrounded by, and flirting with, other women, a cha-cha-cha begins to play. She approaches him wanting to dance. He asks her, “¿Quieres bailar para mi, mulata?” (Do you want to dance for me, mulata?), and then proceeds to lift her up onto the bar which doubles as an elevated stage. She starts to cha-cha-cha, not only for him, but for the entire cabaret. I read her dance as a corporeal affront to Martín having ignored her. Initially, it appears as if she dances to please him, however, with each flip (dip, sway, pulse, pump) of her hips, she carves out a hip(ped) response to not just having been ignored by him and what he expects/wants from her, but by what he represents: machista notions of being. The cabaret audience adds to Caridad's affront, showing how her dancing body can attract more than one pair of eyes (see Figure 5).

Figure 5. Video still from Mulata (1954). Photo by author. Caridad improvises her cha-chacha, garnering an attentive audience.

The pleasure involved in her "hip poetics" represents the pleasure Caridad insisted she has not had up until leaving her hometown and going to Havana with Martín: Nunca me imaginé que existiera tanta felicidad, I never imagined that there could exist such happiness, she says to him, while she lays on a bed inside a hotel room in Havana. Subtly couched within a language of phallic virility's ability to give pleasure, almost no allowance remains for Caridad's pleasure to be anything but based on a man. Only when she dances, improvising through a cha-cha-cha, pummeling her audience ever so gently with the enunciating curves of her hips and buttocks, does she seize pleasure ever briefly through her hip(g)nosis.

Hip(g)nosis posits the idea of female sexuality through the body, specifically the hip, as a means for that very body to exhibit power, potentiality, and prowess. It follows, then, that the hipped enunciations of mulatas marked as tropes shift from being erotic suggestions for the patriarchal gaze to becoming historicizing declarations about and for othered women's labor and lives; she is a deployment, a corpo-mulata.

The beginning of her dance number has her filmed from the waist up, leaving the film audience to infer the hip sway occurring beneath. The neighboring bystanders' gazes shift to her dancing body and eventually, the camera pulls away and the film audience gets the opportunity to experience her enunciating hips and buttocks (see Figure 6). 
Figure 6. Video Still from Mulata (1954). Photo by author. Caridad swings her hips as her audience watches her intently.

The cha-cha-cha is a combination of duple and triple time: 1-2, 1-2-3, 1-2, 1-2-3, and so on. When danced, the feet alternate stepping to this rhythm while the arms, torso, and more importantly the hip/butt complex can play with the rhythm by improvising how to move in the space to the rhythm. Because of the alternating foot action and slight weight transfer between them, the hips must sway to the corresponding side of the weighted foot/leg. Ultimately, the hips become the focal point demonstrating the dancing body's finesse. Caridad's cha-cha-cha has her tapping her feet and pumping her pelvis back and forth, like a piston. Between swaying, pulsing, and circulating motions, Caridad's hips mesmerize her audience. The bartender gazes wide-eyed up at her, and even when she moves out of the frame, the camera lingers on his transfixed state showing the effectiveness of those moving hips to indeed hip-notize (see Figures 7 and 8).

Figure 7. A transfixed bartender Figure 8. He can't take his eyes stares wide-eyed. off of her dancing body. Video Stills from Mulata (1954). Photos by author.

Guevara, the cabaret owner, arrives during her "show." Several point-of-view shots from his perspective situate Caridad as the spectacle of the cabaret. Martin goes over to speak with him and we find out he has unsettled debts. Guevara offers Martin money only if Martin can persuade "la mulata" to work for him. For them, she exists as an exchangeable commodity going from one man to another: Convencela que se quede aqui y firme un contrato conmigo y yo te consigo el dinero para rescatar tu barco (Convince the mulata to stay here and sign a contract with me and I'll help you find the money to get your boat back), Guevara enticingly offers Martín. Quick to demonstrate which "item" he prefers, Martín abandons Caridad to the life of the cabaret. After Martín leaves, Guevara conveys the news to her in his office. She has been "sold" for a boat:

¿Ahora qué vas a hacer, mulata?

Now what are you going to do, mulata?

She throws a shot glass, walks over to the door, and opens it to look out onto the cabaret. She turns, looks straight at Guevara and says:

Siempre nos han vendido. Nos han tenido como esclavos. Pero ahora yo, la esclava mulata va a vengarse. Martín y tú, mi nuevo dueño, quieren que yo me queme en el infierno del baile. ¡Jmf! ¡Pero muchos van a arder conmigo!

They've always sold us. They've kept us as slaves. But now, I, the mulata slave will avenge herself. Martin and you, my new owner, want me to burn in the hell of the cabaret. Hmph!

But a lot of people will burn with me!

Having been "abandoned" and "sold" to the cabaret, a quick edit cuts to Caridad's triumphant entrance onto the cabaret after she pronounces her revenge.

The Mulata's Revenge

Caridad enters stage left with arms diagonally stretched outwards from her body, presenting that very same body to an audience. As she enters facing front, she continues with elevated arms to move sideways/across the elevated stage. Her hips below snap to the left and then to the right, like a rhythmic pendulum. She executes a small, syncopated jump-almost like a double jump-and then the hip that corresponds to the foot where her weight has shifted to, punctuates the downbeat. These "jumps" are abrupt, quick knee flexion bounces with alternating hip pumps from side to side (see Figures 9 and 10). 
Figure 9. Video Still from Mulata (1954), Photo by Author. Caridad makes her grand entrance at the Cabaret Las Vegas.

Figure 10. Video Still from Mulata (1954), Photo by Author. Caridad shakes her hips briefly.

When she arrives stage right, hips swinging from side to side and arms still above, she descends stairs that take her through tables filled with cabaret onlookers. While she walks down the steps, she shimmies her shoulders and brings her arms down to be level with her shoulders and suddenly pauses. She does basic rumba steps with corresponding hip swirls, takes the last two steps and when she arrives at ground level that is the cabaret main floor, she straightens her legs, bends her torso forward and salutes an onlooker behind her with her bottom jutting out (see Figure 11).

Figure 11 Video Still from Mulata (1954), Photo by Author. Caridad stops suddenly and pushes her hips and buttocks back into a riveted and hip-notized spectator.

Her bottom hides behind a huge multi-layered tulle bow and train that bobs according to her pelvic enunciations. She continues on the main cabaret floor, flutters her shoulders and traces a full circle around the floor to wind up in the center facing forward. She has been shot wide angle up until now, allowing the audience outside of the film set to ingest her entire moves on the screen and to witness the audience within the film's reaction.

What follows is a series of improvised rumba steps with legs bending and weight shifts enabling hip dips, sways, swirls, and circles. After several counts of the rumba step facing her audience, she turns around and the big white tulle bow makes figure eights, illustrating the shapes her hips trace in space. Perhaps she thinks we may not have had enough of her big white bow, so she does a quick jump, leans forward with her back still to us, and on the balls of her feet she runs in place, tracing little circles with her hips/butt/bow. Circles become semi-circles become ovals become half circles swinging side to side like a swing set, all at the discretion of the rhythm and this corpo-mulata-cum-rumbera's improvisational technique. She kicks one leg towards the drummers (who play in front of her when her back is to the audience) and turns around to face her adoring public once again. Camera shots are generally wide ones, encapsulating her entire dancing body, permitting ample witnessing of how it not only moves through the cabaret space, but how other corpo-reals react to its moving and performing presence. All eyes rest on this dancing corpo-mulata. She is the main attraction, the cocktail special of the evening: the new infamous Mulata served at Cabaret Las Vegas. By performing hip rotations, undulations, and pelvic movements associated with her presupposed intemperate sexuality and brazen nature, through an acute awareness of the material value of those kinesthetic iterations, the corpo-mulata appropriates the very body that has been used against her. This is hip(g)nosis at work. In so doing, she removes her body's status as fetish, as violence and iconographic subjugation, while at the same time highlighting the socio-politically constructed nature of race. It is through this performativity based on epidermal realities that she asserts her historically denied subjectivity and makes claims for citizenship. Thus, her body serves as both cultural construct and site of redress, further complicating notions of race, gender, and subjectivity. The corpo-mulata moves, entrenched in a consistent struggle between the state, consumerism and consumption, machismo in all of its different cultural forms, and her construction of self-hood attesting to the fact that "power is everywhere; not because it embraces everything, but because it comes from everywhere."(Foucault 1977, 93). If this is the case, then there lies power in the practice of corpo-mulata and in the theory/sign/movement of hip(g)nosis. It is not simply the power to dazzle, enliven, enthrall, swindle, or entice, but the power to contest the multiplicity of force 
relations acting upon that body. She can thus enact a contestatory resistance through the seemingly "natural" revolution of her hips (see Figure 12).

Figure 12 Video Still from Mulata (1954), Photo by Author. Caridad makes figure eights and circles with her hips, accented by the tulle bow.

At the refrain of the "bow dance," the camera moves in for a tighter shot. This time, she inhabits the frame from mid-thigh to the top of her headdress, and we see the bow move closer. Interchanging between wide and medium close shot, she continues to hip-notize her public (see Figure 13).

Figure 13 Video Still from Mulata (1954), Photo by Author. Mid-frame close up of her hip circles with the bow moving with her.

Another barrage of rumba steps follow as the buttocks leads the way back towards the drummers, all combined with fancy footwork: jump, cross right in front, across left, jump cross left in front, across right. During a drum solo she imitates the male version of the rumba, the columbia in that she lifts her knees alternating them while her torso quickly rotates from left to right, the movement initiated by the waist, hips stable. With her back to the audience yet again, she jumps and lands on the floor, knees bent, back arching until she touches the floor with her back, neck craned to look at audience. Meanwhile her arms are outstretched, perpendicular to her torso and she shimmies her shoulders to another percussive drum solo, while lying half supine on the floor. When she gets up, her energy and pace slows down, she does several rumba steps facing the audience, stops as the music flourishes to an end, lifts her arms triumphantly and smiles. A corpo-mulata's Vengeance achieved through hip(g)nosis (see Figure 14).

Figure 14 Video Still from Mulata (1954), Photo by Author. She finishes her performance and raises her arms to the thunder of applause.

These examples of hip(g)nosis within the confining narrative of the mulata Caridad acknowledge hip(g)nosis' ability to assert the corpo-real's lived presence. What is more, hip(g)nosis forges a real or, quite specifically, a material response to the impositions of the interpellated mulata-sign. If body movements, or more precisely, if a corpo-real's wielding of her own body/body part can be considered an assertion of identity, a veritable choreography of the self, then it becomes crucial to consider bodies-racialized, gendered, sexualized and sensual-as sites of knowledge, history and power.

\section{REFERENCES}

Blanco Borelli, M. 2006. A Case of Hip(g)nosis: An Epistemology of the Mulata Body and her

Revolutionary Hips. Ph.D Dissertation. UC Riverside.

Foucault, M. 1977. Discipline and Punish: The Birth of the Prison. New York: Vintage Books.

González, R. 2002. Cine Cubano: Ese ojo que nos ve. San Juan: Editorial Plaza Mayor. 
Hartman, S. 1997. Scenes of Subjection: Terror, Slavery, and Self-Making in NineteenthCentury

America. New York: Oxford University Press.

Martínez Solares, Gilberto, dir. 1954. Mulata. Tekila Films, DVD 2005.

Moore, R. 1997. Nationalizing Blackness: Afrocubanismo and Artistic Revolution in Havana, 1920-1940, Pittsburgh: U Pittsburgh Press.

Piedra, J. 1997. "Hip Poetics," In Everynight Life: Culture and Dance in Latin/o America, edited

by Celeste Fraser Delgado and José Estaban Muñoz, Durham: Duke University Press.

Ramos, C. March 2006. Phone conversation/interview.

Scott, A. B. 2001. "Dance” In Culture Works: The Political Economy of Culture.

Minneapolis:

University of Minnesota Press.

-. 2002. "Articulations of Blackness in Salvador Bahia, Brasil" (paper presented at the meeting entitled Blackness in Global Contexts: Reflections on Experiences of Blackness from a Transnational Perspective, UC Davis. 